\title{
An Annotated Checklist of the Mammals of Kuwait
}

\author{
Peter J. Cowan
}

\begin{abstract}
Department of Biological Sciences and Chemistry, Nizwa University, P.O.Box 33, PC 616 Birkat Al-Mouz, Nizwa, Sultanate of Oman, Email: desertmammal@yahoo.com.
\end{abstract}

\begin{abstract}
An annotated checklist of the mammals of Kuwait is presented, based on the literature, personal communications, a Kuwait website and a blog and the author's observations. Twenty five species occur, a further four are uncommon or rare visitors, six used to occur whilst another two are of doubtful provenance. This list should assist those planning desert rehabilitation, animal reintroduction and protected area projects in Kuwait.
\end{abstract}

Keywords: Mammalia; Kuwait; the Gulf; Conservation; Reintroduction.

$$
\text { قائمة بالحيوانات الثدية في دولة الكويت }
$$

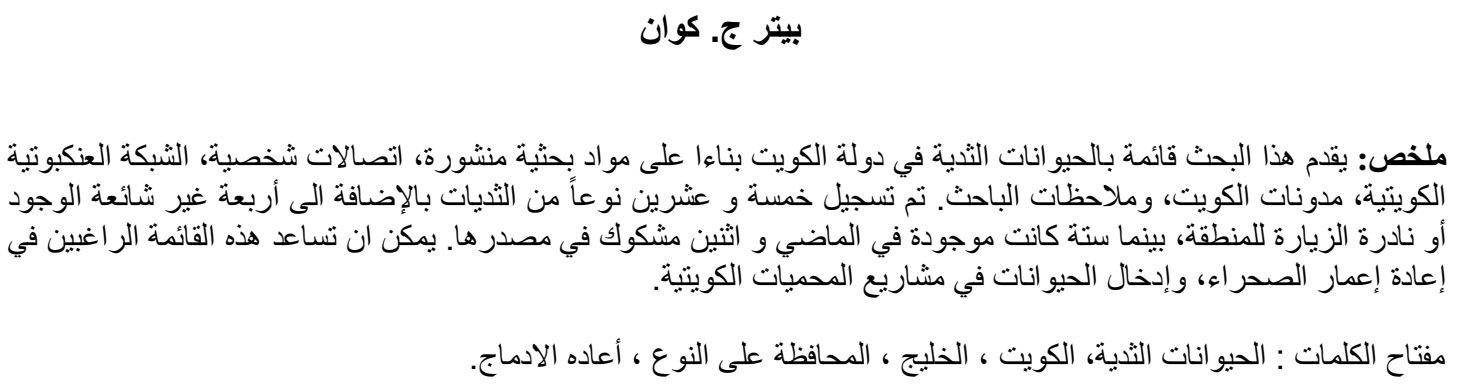

\section{Introduction}

This annotated checklist of the non-domesticated mammals of Kuwait is intended to be of use to those planning forthcoming desert rehabilitation, animal reintroduction and protected area projects there, funded by the United Nations Compensation Commission (UNCC, 2005), and to stimulate further field research, especially into Kuwait's rodents (Rodentia) and bats (Chiroptera). Harrison and Bates' (1991) volume on the mammals of Arabia is the single most useful source for Kuwait's terrestrial mammals but otherwise the literature is scattered and often difficult to obtain.

The scientific nomenclature and sequence I have used for terrestrial mammal species is that of Harrison and Bates (1991) with one exception. Gazella saudiya (Kingswood et al., 2001) was treated by Harrison and Bates (1991) as a subspecies of Gazella dorcas. The Cetacea follow the 'Conservation checklist' of Shirihai (2006) and have been inserted before the artiodactyls. Frequently cited references are AbdulRahman Al-Sirhan's (2012) photographic website on the wildlife of Kuwait, Clayton (1983), Clayton and Wells (1987), Harrison and Bates (1991) and Mike Pope's (2012) photographic blog on the birds and other wildlife of Kuwait. PJC stands for author's observations.

Thirty seven species are listed in the systematic list below. Twenty five constitute the present Kuwait mammalian fauna, indicated by PKMF after the authority citation of the scientific name. Four species are uncommon or rare visitors to Kuwait (RV), six used to occur in Kuwait (EX) and two are of doubtful provenance (DP).

\section{Systematic list}

\section{INSECTIVORA}

Long-eared hedgehog Hemiechinus auritus (Gmelin 1770) PKMF

Fairly common resident (Clayton, 1983; Clayton and Wells, 1987; Harrison and Bates, 1991; Al-Sirhan, 2012; Pope, 2012; PJC). An inhabitant of Eissa et al.'s (1975) study area in southeast Kuwait. 


\section{P.J. COWAN}

Ethiopian hedgehog Paraechinus aethiopicus (Ehrenberg 1833) PKMF

Uncommon or rare resident (Clayton, 1983; Clayton and Wells, 1987). One Al-Salmi, western Kuwait, April 2007 (Al-Sirhan, 2009; Al-Sirhan, 2012).

\section{CHIROPTERA}

Naked-rumped tomb bat Taphozous nudiventris Cretzschmar 1830 PKMF

Rare visitor presumably from Iraq (Clayton, 1983; Clayton and Wells, 1987). Large roost of ca. 500 or more found at a farm on outskirts of Kuwait city 16 September 2002 (Al-Sirhan, 2007; Al-Sirhan, 2012). Flying individuals there at sunset early December 2007 after "many bats erupted from one of the farm buildings" (Pope, 2012). Photographed at the farm April 2008 and 2009 and droppings found there November 2007 and December 2009, all suggesting it is a regular roost site and that the bats may well be resident (Al-Sirhan, 2009).

Trident leaf-nosed bat Asellia tridens ( E. Geoffroy 1813) RV

Uncommon or rare visitor presumably from Iraq (Clayton, 1983; Clayton and Wells, 1987).

Kuhl's pipistrelle Pipistrellus kuhlii (Kuhl 1819) PKMF

Fairly common urban resident (Clayton and Wells, 1987; Harrison and Bates, 1991).

\section{CARNIVORA}

\section{Wolf Canis lupus Linnaeus 1758 EX}

Occurred but apparently no longer present (Clayton and Wells, 1987; Harrison and Bates, 1991).

Red fox Vulpes vulpes (Linnaeus 1758) PKMF

Common resident (Clayton and Wells, 1987; Harrison and Bates, 1991; Al-Sirhan, 2012; Pope, 2012; PJC).

Fennec fox Vulpes zerda (Zimmermann 1780) DP

There are two specimens known from Arabia if the Sinai is excluded. One was obtained in Kuwait and sent to London in 1935 and one from southern Iraq was reported in 1982 (Gasperetti et al., 1985; Harrison and Bates, 1991). A third, an animal captured live near Jebel Hafit (UAE/Oman border) and put in Al-Ain zoo, was actually a Rüppell's fox Vulpes rueppellii (Harrison and Bates, 1991). The fennec fox is a Saharan species that occurs as far east as the Sinai in Egypt (Asa et al., 2004) and is often kept in captivity. It is suspicious that there are no other Arabian records, casting doubt on the provenance of the Kuwait and Iraq individuals (Stuart and Stuart, 2008).

Omar and Abdulraheem (1996) stated that "Red and fennec foxes (Vulpes vulpes and Fennecus zerda) have been seen in Umm Ar-Rimman and Jal Az-Zor [nearby sites in Kuwait]..." and included the fennec fox in a list of species likely to be encountered within the Jal Az-Zor national park. They presented no proof for these fennec fox records young red and Rüppell's foxes in the field are easily mistaken for fennec fox (e.g. Gasperetti et al., 1985). In an earlier publication on the Jal Az-Zor national park, Omar et al. (1986a) noted that Kuwaiti senior citizens remembered the fennec fox and presented a photo captioned, "Fennec Fox, rare and endangered mammalian species", which in fact depicts a red fox. Omar et al. (1986b) proposed reintroducing [sic] the fennec fox into the Jal Az-Zor national park. Alsdirawi and Faraj (2004) listed the presence of fennec fox in the Kuwait border demilitarised zone without proof but presumably on the basis of the Kuwait and Iraq individuals.

Honey badger Mellivora capensis (Schreber 1776) PKMF

Rare resident (Clayton, 1983; Clayton and Wells, 1987; Harrison and Bates, 1991). Sighted occasionally in the Sabah Al-Ahmad natural reserve (Jal Az-Zor national park) (Al-Sirhan, 2007). Captive individual photographed in 2002 (Al-Sirhan, 2012) apparently of African origin.

Indian grey mongoose Herpestes edwardsi (E. Geoffroy 1818) PKMF

Clayton and Wells (1987) stated: “As recently as forty years ago they [Indian grey mongooses] were reported as being very common in Kuwait City. However, they are unlikely to be found in the modern city and nowadays have been relegated to outlying districts such as Jahra or Fahaheel." They probably originated as stowaways on trading dhows or as escaped pets (Clayton and Wells, 1987). A specimen was obtained from Kuwait (Harrison and Bates, 1991).

Wildcat Felis silvestris (Schreber 1777) PKMF

Recorded (Clayton, 1983; Clayton and Wells, 1987; Harrison and Bates, 1991) and perhaps still present. Sand cat Felis margarita (Loche 1858) PKMF

Kitten photographed at Wafra on the Kuwait border (Harrison and Bates, 1991). Several live individuals, apparently caught in Kuwait, were donated to the Desert Animal Facility (Kuwait Institute for Scientific Research, 
Kabd) and The Scientific Center (Kuwait city) from 2001 (Delima, 2006; Bebehani, 2008; PJC). Al-Sirhan (2007) saw four in the Jal Az-Zor national park 26 June 2003 and photographed two of them (Al-Sirhan, 2012).

\section{Caracal Caracal caracal (Schreber 1776) EX}

Recorded (Clayton and Wells, 1987; Harrison and Bates, 1991) but apparently no longer present.

Cheetah Acinonyx jubatus (Schreber 1776) EX

Reported from the Kuwait area (though not necessarily from within what are the present-day boundaries of Kuwait) but presumably now long extinct (Clayton and Wells, 1987; Harrison and Bates, 1991).

\section{CETACEA}

\section{Sei whale Balaenoptera borealis Lesson 1828 RV}

In March 1999 a $10 \mathrm{~m}$ long whale carcass was washed ashore and eventually identified as B. borealis (Bishop and Alsaffar, 2008).

Blue whale Balaenoptera musculus (Linnaeus 1758) RV

The skeleton of a whale stranded at Kadhima in June 1963 and placed in the 'Natural History Museum' was identified as that of B. musculus by Al-Robaae (1971b), who sent photographs of the skeleton and notes to F.C. Fraser of the British Museum (Natural History). Fraser replied "I...have no doubt about the genus of the animal concerned. It is Balaenoptera, I am not quite certain of the species...I am inclined to say that it is Balaenoptera musculus rather than Balaenoptera physalus, basing this on the shape of the nasals" (Al-Robaae, 1971b). The skeleton is now in the 'Educational Science Museum' (visited April 2007). A second skeleton there is labelled as a blue whale length $6.5 \mathrm{~m}$ from the Khowaysat area between Kadmah and Doha 10 October 1976. A third specimen, caught north of Shuaiba industrial area on 26 December 1980 and measuring $7 \mathrm{~m}$ in length, is also on display there (Nithyanandan, 2010a).

Indo-Pacific humpback dolphin Sousa chinensis (Osbeck 1765) PKMF

Occurs (Henningsen and Constantine, 1992). Observed year-round in the north off Boubyan island with a maximum pod size of 30 individuals, and routinely observed in Kuwait bay (Bishop and Alsaffar, 2008), though also recorded off Fahaheel and in the south off Khiran (Willson, 2007). Recent sightings between Mina Al-Zour and Khiran included calves (Nithyanandan, 2010b; Pope, 2012).

Indo-Pacific bottlenose dolphin Tursiops aduncus (Ehrenberg 1833) PKMF

Farmer (1983) stated, "The commonest dolphin [of Kuwait] is probably Tursiops aduncus..." and included two photos of live T. aduncus. Found year round though with fewer winter sightings, the majority seen in southern waters from Fahaheel southwards (Willson, 2007; Pope, 2012).

False killer whale Pseudorca crassidens (Owen 1846) RV

A specimen was found south of Kuwait city in 1964. Its skeleton was mounted and displayed in the 'Natural History Museum', Kuwait (Al-Robaae, 1971a).

Finless porpoise Neophocaena phocaenoides (G. Cuvier 1829) PKMF

Farmer (1983) noted this species had been recorded and included a photo of a stranded individual. Henningsen and Constantine (1992) reported a group of two and a group of five in Kuwait bay about $2 \mathrm{~km}$ from shore. Andrew Willson (2007) reported several sightings and strandings.

\section{ARTIODACTYLA}

Arabian oryx Oryx leucoryx (Pallas 1777) EX

O. leucoryx presumably occurred in the western and northwestern deserts of Kuwait prior to 1900 (Kingswood et al., 2001). Reintroduction into Kuwait has been recommended (Omar et al., 1986b; Omar and Abdulraheem, 1996), though a protected area of considerable size would be needed, involving adjacent countries (Kingswood et al., 2001; Alsdirawi and Faraj, 2004).

Mountain gazelle Gazella gazella (Pallas 1766) DP

Although intimated to have occurred (Clayton and Wells, 1987), it would seem most unlikely that this species, an inhabitant of the mountainous and nearby areas of the Arabian peninsula, has ever occurred naturally in Kuwait (Harrison and Bates, 1991; Kingswood et al., 2001).

Saudi gazelle Gazella saudiya (Carruthers and Schwarz 1935) EX

This species has been recorded (Harrison and Bates, 1991) and suggested for reintroduction (Omar et al., 1986b). However, Saudi gazelle is now considered extinct in the wild and may well be extinct in captivity too, as certain claimed captive G. saudiya populations have been shown not to be so (Kingswood et al., 2001; Hammond et al., 2001). 


\section{P.J. COWAN}

Dunham et al. (2001) cast doubt on the existence of the species in the past in Kuwait: "Historically, this species was recorded on the western side of the Arabian Peninsula, with all records west of $47{ }^{\circ} \mathrm{E}$ except for one anomalous specimen from Kuwait, which reached the British Museum after a period of captivity at London Zoo... Recent DNA studies indicate that a record for Iraq (Harrison and Bates, 1991) refers to a sand gazelle [G. subgutturosa] (R. Hammond, personal communication)."

Goitered gazelle Gazella subgutturosa (Guldenstaedt 1780) EX

The taxon that occurred in Kuwait was the Arabian sand gazelle Gazella subgutturosa marica (Harrison and Bates, 1991; Kingswood et al., 2001). Any reintroduction plan (Omar et al., 1986b; Omar and Abdulraheem, 1996) needs to be aware of the genetic background of stock (Harrison and Bates, 1991; Kingswood et al., 2001).

\section{LAGOMORPHA}

Cape hare Lepus capensis (Linnaeus 1758) PKMF

Recorded (Harrison and Bates, 1991) and perhaps still present. Any reintroduction plan (Omar et al., 1986b; Omar and Abdulraheem, 1996) would require geographically appropriate animals (Harrison and Bates, 1991).

\section{RODENTIA}

Indian crested porcupine Hystrix indica Kerr 1792 PKMF

A few quills were collected in the Kuwait/Saudi Arabia border area in Wadi al Batin, February 1995 by S.T. Spencer and C.W.T. Pilcher (Spencer, 2009).

Euphrates jerboa Allactaga euphratica Thomas 1881 PKMF

Occurs but apparently rare (Clayton, 1983; Harrison and Bates, 1991). An inhabitant of Eissa et al.'s (1975) study area in southeast Kuwait. One photographed (Al-Sirhan, 2008) in western Kuwait April 2007.

Lesser jerboa Jaculus jaculus (Linnaeus 1758) PKMF

Common (Clayton, 1983; Harrison and Bates, 1991; Al-Sirhan, 2012; Pope, 2012; PJC). Eissa et al. (1975) studied the ecology of this species at a site in southeast Kuwait. At the Jal Az-Zor escarpment, remains of Jaculus jaculus were found in 18 of 97 little owl Athene noctua pellets and Jaculus jaculus hind limbs and tails at little owl feeding sites (Clayton, 1991).

Black rat Rattus rattus (Linnaeus 1758) PKMF

Apparently present but declining (Clayton, 1983).

Brown rat Rattus norvegicus (Berkenhout 1769) PKMF

Locally common (Clayton, 1983; Clayton and Wells, 1987; Harrison and Bates, 1991).

House mouse Mus musculus Linnaeus 1758 PKMF

Present (Clayton, 1983; Harrison and Bates, 1991).

Baluchistan gerbil Gerbillus nanus Blanford 1875 PKMF

Present and commoner than G. dasyurus (Clayton, 1983; Clayton and Wells, 1987; Harrison and Bates, 1991).

Wagner's gerbil Gerbillus dasyurus (Wagner 1842) PKMF

Present (Clayton, 1983; Clayton and Wells, 1987).

Cheesman's gerbil Gerbillus cheesmani Thomas 1919 PKMF

Present (Clayton, 1983; Harrison and Bates, 1991; Al-Sirhan, 2012; PJC). Remains found in 13 of 97 little owl pellets collected at the Jal Az-Zor escarpment (Clayton, 1991).

Indian gerbil Tatera indica (Hardwicke 1807) PKMF

Present (Alyan, 1989; Harrison and Bates, 1991). Probably eradicated by the Kuwait Ministry of Health (AlSirhan, 2009).

Libyan jird Meriones libycus Lichtenstein 1823 PKMF

Common in some desert areas (Clayton, 1983; Clayton and Wells, 1987; Al-Sirhan, 2012; Pope, 2012; PJC). Remains found in 44 of 97 little owl pellets collected at the Jal Az-Zor escarpment (Clayton, 1991).

Sundevall's jird Meriones crassus Sundevall 1842 PKMF

Present (Clayton, 1983; Harrison and Bates, 1991; Al-Sirhan, 2012; PJC). 


\section{Discussion and Conclusions}

Kuwait's general environment has been described by El-Baz and Al-Sarawi (2000) and Al-Yamani et al. (2004), its flora by Omar (2000), insects by Al-Houty (1989) and birds by Cowan and Pilcher (2003), Gregory (2005) and Pope and Zogaris (2012). The current paper presents an annotated checklist of the Kuwait mammalian fauna. Twentyfive species constitute the present Kuwait mammalian fauna, 22 are terrestrial species and three marine (cetaceans). An additional four species are uncommon or rare visitors to Kuwait (one bat, three cetaceans). Six species used to occur in Kuwait, either larger carnivores (wolf, caracal, cheetah) or ungulates (Arabian oryx, Saudi gazelle, Arabian sand gazelle). The Kuwait desert is in very poor condition with considerable vegetation degradation (Brown, 2003) and uncontrolled hunting (Pope and Zogaris, 2012). The Jal Az-Zor 'national park', to the north of Kuwait bay, is fenced and protected. Otherwise there are some protected coastal wetland sites and some areas that receive inadvertent protection (military sites, airports, oil fields). More extensive areas need protection. They should be fenced first, a ranger service initiated and then inventoried. The marine environment also needs extensive reserves, which should include the coral islands.

\section{Acknowledgement}

Dr Jim Bishop (KISR) supplied me with copies of several elusive marine mammal papers.

\section{References}

AL-HOUTY, W. 1989. Insect Fauna of Kuwait. University of Kuwait, Kuwait.

AL-ROBAAE, K. 1971a. False Killer Whale Pseudorca crassidens; a New Record for Arab Gulf. Bulletin Iraq National History Museum, 5(1): 31-34.

AL-ROBAAE, K. 1971b. Notes on a Blue Whale (Balaenoptera musculus) Skeleton in Natural History Museum, Kuwait. Bulletin Iraq National History Museum, 5(1): 43-44.

ALYAN, S.M.H.H. 1989. Biological Studies of Tatera indica (Hardwicke, 1807), the Indian Gerbil, in Kuwait Desert. MSc Thesis (Zoology). Kuwait University, Kuwait.

ASA, C.S., VALDESPINO, C. and CUZIN, F. 2004. Fennec Fox Vulpes zerda (Zimmermann, 1780). In Canids: Foxes, Wolves, Jackals and Dogs. (Eds.) SILLERO-ZUBIRI, C., HOFFMANN, M. and MACDONALD, D.W. IUCN, Gland, Switzerland. pp. 205-209.

AL-SIRHAN, A.R. 2007, 2008, 2009. Personal communs.

AL-SIRHAN, A.R. 2012. Wildlife of Kuwait. www.alsirhan.com/Animals. (last accessed 5 October 2012).

AL-YAMANI, F.Y., BISHOP, J., RAMADHAN, E., AL-HUSAINI, M. and AL-GHADBAN, A.N. 2004. Oceanographic Atlas of Kuwait's Waters. Revised edition. Kuwait Institute for Scientific Research, Kuwait.

ALSDIRAWI, F. and FARAJ, M. 2004. Establishing a Transboundary Peace Park in the Demilitarised Zone (DMZ) on the Kuwaiti/Iraqi borders. Parks, 14(1): 48-55.

BEBEHANI, S. 2008. Personal commun.

BISHOP, J.M. and ALSAFFAR, A.H. 2008. Quantitative Observations on Marine Mammals and Reptiles of Kuwait's Boubyan Island. Zool. Middle East, 43: 3-12.

BROWN, G. 2003. Factors Maintaining Plant Diversity in Degraded Areas of Northern Kuwait. J. Arid Environments, 54: $183-194$.

CLAYTON, D. 1983. Mammals. In Kuwait's Natural History: an Introduction. (Eds.) CLAYTON, D. and PILCHER, C. Kuwait Oil Company, Kuwait. 172-190.

CLAYTON, D.A. 1991. The Little Owl Athene noctua and its Food in Kuwait. Sandgrouse, 13: 2-6.

CLAYTON, D. and WELLS, K. 1987. Discovering Kuwait's Wildlife. Fahad Al-Marzouk, Kuwait.

COWAN, P.J. and PILCHER, C.W.T. 2003. The Status of Desert Birds in Kuwait. Sandgrouse, 25: 122-125.

DELIMA, E. 2006. Personal commun.

DUNHAM, K.M., WILLIAMSON, D.T. and JOUBERT, E. 2001. Saudi Arabia. In Antelopes. Part 4: North Africa, the Middle East, and Asia. (Eds.) MALLON, D.P. and KINGSWOOD, S.C. IUCN, Gland, Switzerland. pp. 55-62.

EISSA, S.M., EL-ZIYADI, S.M. and IBRAHIM, M.M. 1975. Autecology of the Jerboa Jaculus jaculus Inhabiting AlJalia Desert Area, Kuwait. J. Univ. Kuwait (Sci.), 2: 111-120.

EL-BAZ, F. and AL-SARAWI, M. (Eds.). 2000. Atlas of the State of Kuwait from Satellite Images. Kuwait Foundation for the Advancement of Sciences, Kuwait.

FARMER, T. 1983. Marine life. In Kuwait's Natural History: an Introduction. (Eds.) CLAYTON, D. and PILCHER, C. Kuwait Oil Company, Kuwait. pp. 192-246.

GASPERETTI, J., HARRISON, D.L. and BÜTTIKER, W. 1985. The Carnivora of Arabia. Fauna Saudi Arabia, 7: 397-461.

GREGORY, G. 2005. The Birds of the State of Kuwait. Gregory, Skegness, UK.

HAMMOND, R.L., MACASERO, W., FLORES, B., MOHAMMED, O.B., WACHER, T. and BRUFORD, M.W. 2001. Phylogenetic Reanalysis of the Saudi Gazelle and its Implications for Conservation. Conservation Biology, 15: $1123-1133$. 


\section{P.J. COWAN}

HARRISON, D.L. and BATES, P.J.J. 1991. The Mammals of Arabia. Second Edition. Harrison Zoological Museum, Sevenoaks, UK.

HENNINGSEN, T. and CONSTANTINE, R. 1992. Cetaceans in the Persian Gulf: After the War. Sixth Annual Conference European Cetacean Society, San Remo, Italy February 1992. 108-113.

KINGSWOOD, S.C., COWAN, P.J. and CLAYTON, D.A. 2001. Kuwait. In Antelopes. Part 4: North Africa, the Middle East, and Asia. (Eds.) MALLON, D.P. and KINGSWOOD, S.C. IUCN, Gland, Switzerland. pp. 84-87.

NITHYANANDAN, M. 2010a. Personal commun.

NITHYANANDAN, M. 2010b. Opportunistic Sightings of Indo-Pacific Humpback Dolphin, Sousa chinensis from Kuwait Waters with Notes on their Behaviour. J. of the Marine Biological Association of India, 52(1): 19-23.

OMAR, S.A.S. 2000. Vegetation of Kuwait. Kuwait Institute for Scientific Research, Kuwait.

OMAR, S.A.S. and ABDULRAHEEM, M.Y. 1996. Measures to Conserve the Wildlife of Kuwait. In Conservation of Arabian Gazelles. (Eds.) GRETH, A., MAGIN, C. and ANCRENAZ, M. National Commission for Wildlife Conservation and Development, Riyadh. 149-158.

OMAR, S.A., AL-SDIRAWI, F., AGARWAL, V., HAMDAN, L., AL-BAKRI, D. and AL-SHUAIBI, F. 1986a. Criteria for Development and Management of Kuwait's First National Park/Nature Reserve. Vol. 1 Inventory and Zoning. Kuwait Institute for Scientific Research, Kuwait.

OMAR, S.A., TAHA, F.K., AL-SDIRAWI, F. and AL-SHUAIBI, F. 1986b. Criteria for Development and Management of Kuwait's First National Park/Nature Reserve. Vol. 2 Reintroduction, Management and Legal Land Use. Kuwait Institute for Scientific Research, Kuwait.

POPE, M. 2012. Birding Kuwait/Kuwait Birding. www.hawar-islands.com/blog/14_stub.php, http://kuwaitbirding.blogspot.com. (both last accessed 5 October 2012).

POPE, M. and ZOGARIS, S. (Eds.). 2012. Birds of Kuwait. Kuwait Foreign Petroleum Exploration Company, Kuwait and Biodiversity East, Nicosia.

SHIRIHAI, H. 2006. Whales, Dolphins and Seals. A and C Black, London.

SPENCER, S.T. 2009. Personal commun.

STUART, C. and STUART, T. 2008. A photographic Guide to Mammals of North Africa and the Middle East. New Holland, London.

UNCC. 2005. Decision Concerning follow-up Programme for Environmental Claims Awards Taken by the Governing Council of the United Nations Compensation Commission at its 150th meeting, on 8 December 2005. S/AC.26/Dec.258. United Nations Security Council, www.uncc.ch/decision/dec_258.pdf. (accessed 5 October 2012).

WILLSON, A. 2007. Personal commun.

Received 10 January 2012

Accepted 16 June 2013 